\title{
THE IDENTITY OF THE CANARY ISLANDS: A CRITICAL ANALYSIS OF COLONIAL CARTOGRAPHY
}

[Received November 14th 2018; accepted February 10th 2019 - DOI: 10.21463/shima.13.1.07]

\section{Ayoze Corujo Hernández}

Postgraduate Centre for Sociological Research, Madrid <ayoze199o.ac@gmail.com>

\begin{abstract}
The Canary Islands is a non-sovereign archipelago that has been incorporated into the Spanish Kingdom since the 14th Century. These islands, located 100 kilometres off the northwest coast of Africa and some $1000 \mathrm{~km}$ from the Spanish peninsular, have been subject to malleable and often distorted representations in different official maps, which have often not reflected the geographical reality of the archipelagic territory. This article investigates the extent to which aspects of colonial history, such as cartography (the spatial element), the precolonial past (the element of historical consciousness) and/or new categorisation as a "European ultraperiphery" (the rhetorical element) have affected the socio-political identity of the Canary Islands. The latter aspects have created an identity characterised by a lack of consciousness of the islands' most obvious characteristic - of their being an (offshore) territory of the African continent. Canarian society has thereby lost its "spatial latitude" (ie an African geographical reality) in favor of a "cognitive latitude" (ie its imagination as an extension of Europe).
\end{abstract}

KEY WORDS: Canary Islands, cartography, colonialism, identity, islands

\section{Introduction}

The Canarian archipelago is one of the seventeen "autonomous communities" of the Spanish state. Autonomous communities have a territorial and institutional character similar to federated states, with their own legislative chambers elected by the population of the territory. In addition, the autonomous communities have many exclusive competencies that make them spaces of governance that are differentiated from other local or national level administrations. Drawing on critical cartography (see Crampton and Krieger, 2010), which posits that maps are expressions of discourse rather than objective expressions of reality, this article will attempt to identify the influence that Spanish cartography has exercised on the elaboration of Canarian identity, thus confirming that the colonial status that has been imposed upon the archipelago has influenced ways of thinking and being in Canary Islands society.

Broadly speaking, what underlies the disjuncture is the discrepancy between the actual location of the territory and the "ideal" or "imaginary" location that has been constructed. The Canary Islands (Figure 1), as an archipelago geographically located off the African

\footnotetext{
${ }^{1}$ This article follows the path of other investigations that have approached the imaginary construction of the Canary Islands, such as Lomanno (2013).
}

Shima <www.shimajournal.org $>$ ISSN: 1834-6057 
continent, some 1,00o kilometers away from the Spanish peninsula (Figure 2) have consistently been mis-located in official Spanish maps, resulting in a cognitive relocation not only among the citizens of the Iberian Peninsula but also amongst the Canarian population itself. This fact had an impact on the construction of the archipelagic society's identity, as a consequence of colonialism, that, even today, is reflected in the islands.

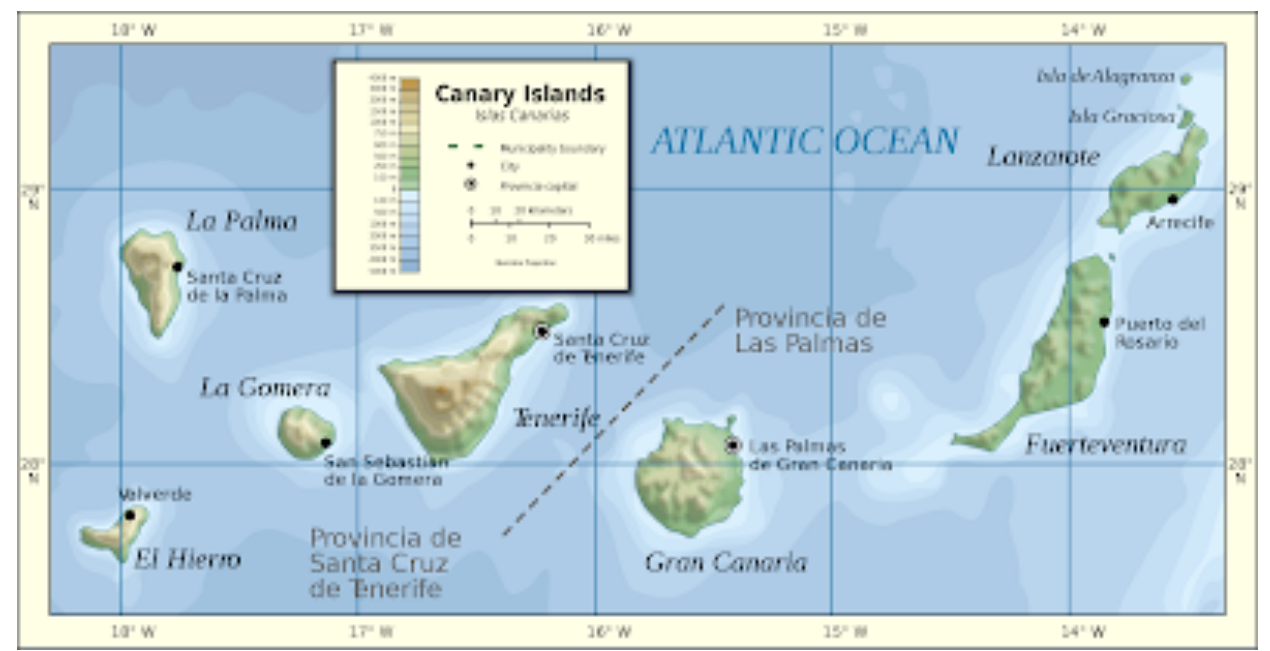

Figure 1 - Map of the Canary Islands (source:

https://www.isladetenerifevivela.com/2013/o7/situacion-geografica-de-la-islas.html).

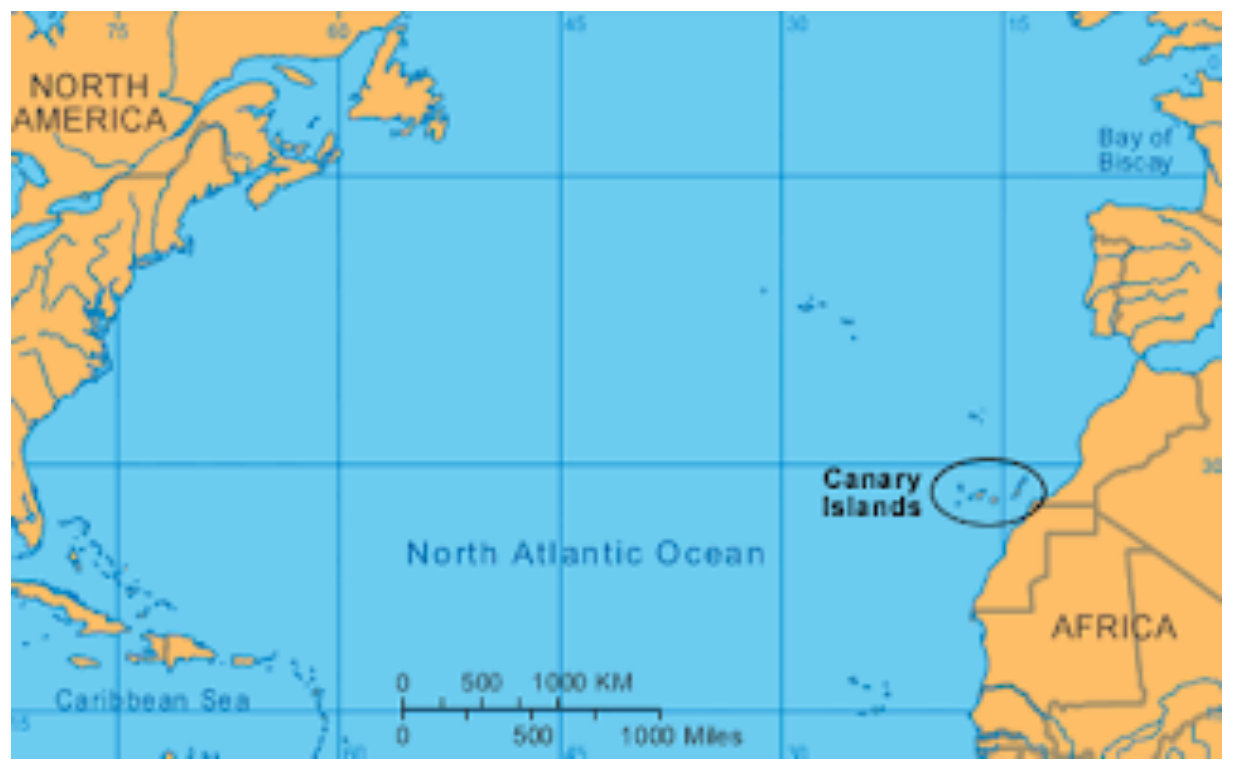

Figure 2 - Map of the Canary Islands' location in the Atlantic Ocean (source: https://www.isladetenerifevivela.com/2013/o7/situacion-geografica-de-la-islas.html). 
Consequently, this work will be structured as follows. After this introduction, the first section will adopt critical approaches to colonial cartography and its influence on the elaboration of the identity of colonial communities (and especially those of island territories) and then will focus on the consequences of the imaginary colonial community from a national point of view, approaching to the islands as archetypes of this phenomenon and connecting it with the colonial cartography. The following sections will analyse the Canary Islands as a case of distorted identity and then Canarian identity will be identified and analysed in greater depth as "colonised" artifice, before the conclusion, which will consider the role of cartography ass explored in the article.

\section{Critical cartography}

The representation of territory through cartographic elaboration is not an objective process but, rather, one that is imbued with subjective and political concerns and factors. Maps, in many instances, do not so much represent an objective reality as constitute an insufflated construction of intentionality that causes the physical reality of place to be distorted. The geopolitical map (and geopolitical cartography in general) seeks to create a standardised product with a political and discursive character that benefits those who have produced it. As identified by Heffernan, "the map, apparently, not only reflects the geopolitical circumstances; if you create it carefully and intelligently, the map can also help to shape these conditions" (2002: 208). That is to say, the map serves both as a mirror of the circumstances and as a creator of the same (or of different aspects of it).

Maps are vulnerable to manipulation. The space represented in them constitutes a fixed image since our environment cannot be observed in a panoramic way through representations that seek, a priori, to be as accurate as possible. In this sense, what we construct cognitively when observing them are spatial imaginaries that help us to locate ourselves in the local, community or global geography (Hiernaux and Lindón, 2012). Thus, maps are effectively compasses that guide us in particular ways depending on the objectives of those who produce them. In the words of Moore and Perdue, "classical geopolitical work and associated cartographies [are] forms of 'situated knowledge' that cannot be divorced from the political motivations and positionality of their makers" (2014: 892).

For Harley (2005), maps maintain an unquestionable rhetorical capacity that visualises a "fictitious world" between the representation and the subject. In the same way, Núñez notes that a map:

is the result of an interaction of the appropriation of the spatial sense: subject and object merge into an effective horizon where understanding is, finally, dialogue - fusion of horizons - between the comprehensive experience - social subject - and the coexistence of the historical horizon of the understanding object. (2017: 152 - author's translation)

Thus, since the first cartographic representations were made in order to be informative for navigators, abstraction and intentionality have been added when elaborating "image maps," that include cosmological, political or religious representations (Montoya, 2007). The first prominent "image maps" occurred in the classical Greek world, where there was a special concern to produce them. The most important Hellenic work is Ptolemy's Geographia, where the first cartographic conflict appears: the location of the meridians and parallels as referents for the measurement that would subsequently be modified according to political convenience (Piccolotto, 2004). But it was not until much later that cartography would 
become increasingly important. In the 15th Century, as maritime expeditions carried out by western empires began to intensify, cartography developed new techniques and dimensions that reflected the new colonial dynamics that were expanding throughout the world. The empires, in their desire to colonise and discover new lands, elaborated their own colonial maps, characterised by an accurate representation of the possessed territories and by being instruments of the exaltation of power with respect to the other competing empires. Thus, the maps became propaganda instruments full of intentionality. As Montoya argues on the moment of European expansion:

It is at this time that cartography emerged as a determinant awareness, both because of the importance of cartographic knowledge in the military sphere, and because of the strategic nature that the cartographic domain acquired in the delimitation, establishment, and support of state sovereignty. (2007: 160 author's translation)

Consequently, it is at this very moment when a close relationship between geography and imperialism was established, elaborating a world system that would revolve around a central area (western countries) and a periphery (the remainder), in a clear reflection of dominance and formal and geographical control (Taylor and Colin, 2002).

\section{Imperialism and the imagination of the colonial community}

Imperialism not only conditioned the spatial contours through cartographic elaboration but was also only one element of the many used for the colonising purpose. As Anderson says in his now famous work Imagined Communities:

the census, the map, and the museum: together, they profoundly shaped the way in which the colonial state imagined its dominion-the nature of the human beings it ruled, the geography of its domain, and the legitimacy of its ancestry. (1991: 243)

It should be mentioned that, according to Anderson's theory, the nation - as a political community - is characterised by its imagination, namely, by the (limited) mental image that its members have of it. Therefore, communities would are molded according to the "imagination" of their members and they construct it based on factors such as history, culture, language and/or other affinities.

Hence, the empires that elaborated national imaginaries both resulted in (and, to varying extents were "co-produced" by) the incorporation of a variety of bureaucratic, military and social activities that took place in the colonial territories, leading to the systematic exploitation of native populations through the introduction of customs and conventions that had nothing to do with the prior realities of the colonised. Following Anderson's thesis, what was generated, for example, in Thailand by Europeans, was a new type of state mentality with traditional structures of political power that attempted to "legitimise" itself through quasi-legal methods. One of these was the use of (what were posed as "historical" maps) that purported to visualise a supposedly "prior/old" relationship between the colony and the metropolis, producing a political-biographical discourse that sought to avoid questioning of the empire. At the same time, and given the need to have a cartographic location for the colonies, the so-called "logo map" emerged, where the territories appeared 
as misplaced pieces in deeply non-geographic maps, positioning the colonies in Western contexts in order to illustrate the chattels and objects of empire in a propagandist form. The direct consequence of this impulse was the progressive penetration of such maps into local social imaginaries with a discernible impact on identity and popular socialisation.

Archaeology was also used as a political tool. The colonists invested in the reconstruction (and, de facto, in the construction) of historical findings and included these in colonial propaganda through a combination of exoticism and attempts to ideologise native peoples. On many occasions, anthropology has been used as a de-legitimising mechanism, considering that so-called "ancestral" populations had little connection with current inhabitants. At the same time, new legitimacies were reinforced, such as that of the protective state, the guarantor of the defense of the cultural and secular heritage that projected its greatness, exalting the charms of the distant, exotic and tropical land. For Anderson (1991), this precisely reflected the great power of the Empire through "logoization", a political-cultural through which in even indigenous rulers ceased to care about their own historical legacy. In Foucauldian terms, the colonial state acted like a panopticon, monitoring, controlling and shaping attitudes without excessive use of violence. In this regard, colonial power was something generic, diffuse and institutional that infiltrated the consciousness of the autochthonous population.

\section{The consequence of the imaginary colonial community: national trivialisation}

The consequences derived from the de facto and "latent" power outlined above have left their mark on the formation of colonial and postcolonial social communities. Following the concept of "banal nationalism" proposed by Billing (2014), what the societies that passed through imperialist logoization experienced was a collective forgetting that led to a markedly banal sense of identity. It should be remembered that for Billing (ibid: 71), the existence of consolidated nations depends on collective amnesia regarding both the past and the present. It follows from the latter that everyday elements of the nation, such as flags or hymns, do not constitute transcendental configurations in the creation of national identity but, rather, elements that are largely unremarked. This entails a routinisation of everything that might a priori sustain national construction that has repercussions on the internal and externa cohesion of the community. For Billing, when the community becomes banal "the imagined community stops being reproduced by acts of the imagination... In the consolidated nations, the imagination ends up being uninhabited and, therefore, inhibited" (ibid: 134). That is to say, the community ceases to have meaning for the citizens if they do not make the effort to imagine it; with it, therefore, being stripped of all meaning. Mystical traits of the nationhood are suspended because there is no cognitive congruence between it and the population that makes it up. Therefore, the identity of the group that supports any community is replaced by a "particularism" devoid of spatial references and oriented towards mimicry between individuals. The immediate effect of this fact is the nonrecognition of an "other". Since there is no a "we", there cannot be a "foreigner" to whom the group can be opposed. According to Tajfel's theory of social identity (1984) individuals must create categories that link their "I" with a "group", since, starting from a specific category, society can be divided into groups. In turn, these must build identity stereotypes to differentiate themselves, causing their behavior to be homogenised among its members.

Thus, colonial communities are be characterised by the absence of that particular "we", inhibiting the capacity to create a national identity that is opposed to an "other". 
Colonialism caused a destruction of the symbolic order of the colonised by incorporating structures that would be internalised by them, and that would lead them irremediably to an acultural and ahistorical confinement. As Salgado and Reyna have expressed, following Fanon (2011):

The colonised arrives in a given world, dispossessed of his previous horizon of understanding. Insofar as this has been overwhelmed, he arrives late in a world that has being imposed on him... In this regard, Fanon asserts, "an inferiority complex arises due to the burial of local cultural originality" and, in this colonised mentality, the colonised wishes to enhance his status and feels a permanent intensification of that desire... He experiences colonisation as a permanent, regenerating anxiety, as the horizon of his interior world is cracked. (2007: 46ss - translation by Marcel Farinelli and Philip Hayward)

\section{Islands as archetypes of a colonial community}

Island territories were amongst the first to suffer the colonial burden, being small places that were vulnerable to foreign invasion (Baldacchino and Royle, 2010). The colonists' perspectives of the islands converted them into mythified, exotic and utopian spaces, prone to being owned as exclusive property. For McCusker and Soares, "historically the island was considered an ideal place, or even a laboratory, in which to materialise the colonial will, free from undesirable foreign influences emanating from the outside" (2011: 10). At the same time, its inhabitants were also perceived and described as "strangers" and/or "different". This is what Baldacchino (2007: 2) points out, citing the anthropologist Firth when he had his first contact with the natives of Polynesia, describing them as "turbulent human material to be induced to undergo a scientific study" (1936: 1).

In the same way, the islands were sites that allowed colonists to explore the strategies they later deployed in vast continental territories; for example, the slave societies operated through the "plantation" systems of the Caribbean, Indian Ocean and the Canary Islands, spaces where the first proto-industrial production models began, based around the sugar mill, cocoa and coffee production (Cubera, 2011). But the islands were also the first pristine territories where an ethnic mixture was forged between the original (or precolonial) settlers and the conquerors and foreigners. At first the indigenous islanders were subdued and enslaved for the most arduous tasks or sold in European and American markets but when these islanders declined, they were replaced by foreign individuals. This was the case in the Canary Islands and the Caribbean, where, as Garcia (2006: 200) has identified, North African Moriscos and sub-Saharans from the Gulf of Guinea and other areas of Africa were imported en masse. Throughout time, this mélange has created island societies (particularly in Latin America and the Caribbean) that are characterised by their "creole" nature. Creole is a term used to refer to the process by which the person or the "self"' is built. For Allen:

Creolization suggests (a) a distancing from the notion of origin and a complication in the reconstruction of a path towards a sense of essence or source; (b) a historical experience of colonialism that gives rise to its use as an "intercultural encounter and the location of the Creole at an intersection, negotiating between identities and forces, and defined by their relocations"; (c) a continuous process with new added ingredients; and (d) a multiplicity of creole forms that make "context and point of view crucial in their understanding." (cited in Cubera, 2011: 14) 
In this way, the process of "creolisation" affects the "how" of the identity construction of colonised societies by influencing the location and sociohistorical and creative circumstances of the community. On the one hand, it can become an assimilation of the colonial culture and identity, mimicking the society of the metropolis, considering it superior to its own; or, on the contrary, it can be an element that encourages national construction by reinforcing an exclusive identity that proclaims itself as a political and sovereign subject distinct from the coloniser.

Elements of creolisation are amplified in territories such as islands. Being finite spaces, the construction of identity is reinforced at the same time that it is imagined to be defended by the sea that surrounds them. Islands themselves create and exclude identities but, at the same time, they suffer from the same logic because they are highly vulnerable to external influences that manage to perpetuate themselves in popular culture. In addition, the sea can resile from that conception of security by acting as a conduit between various cultures. For this reason, the colonial vision of the island as a remote territory "beyond the seas" and born in the heat of its discovery by Europeans, is blurred if one considers that the first conception is the product of ethnocentrism, and the second is a fallacy in itself (since, in most cases, island populations had contact with other peoples before modern European explorers and colonists came to their shores). From this, we can deduce collective imaginaries around islands, their histories and its idiosyncrasies that depart from the truly factual. Colonial language has constructed stereotyped and, in many cases, distorted, interpretations of the term "island", even more so in the geopolitical power relations where these appear as unequal, malleable and vulnerable places in comparison to so-called "inland" territories. Again, McCusker and Soares argue the point with regard to the example of the citizens of Martinique and Guadalupe:

For many years they imagined France as the mother country, suggesting a particularly unfavorable relationship with a very distant (but benevolent) parent and guardian. The islands are very often built as the obedient daughters of the metropolis. (2011: 14).

At present, this parental and protective image of the continent towards "their" islands persists. In a supposedly postcolonial context, the islands still evidence imperial domination by many western countries in a clear example of neocolonialism. According to Jacobs in his book Edge of Empire:

The power structures that gave rise to the empire live in a more disorganized way; in fact, they still officially live in territories, mainly islands, trapped in empires that are, therefore, simultaneously, colonial and postcolonial. (1996:

11)

The islands are the archetype of colonial communities that began with the expeditions of the $14^{\text {th }}$ and $15^{\text {th }}$ centuries.

\section{A critical analysis of the colonial cartography of the Canary Islands}

The political situation of the Canary Islands is a consequence of the colonial processes and imperialist expansion of the 14th and 15th centuries. The archipelago's geostrategic position of tri-continentality, on the way between Africa, Europe, and America, has resulted in many 
imperial powers having an interest in gaining control over it, resulting in a series of clashes between the Canarian population and foreign troops. Nevertheless, it was through the Empire of the Catholic Monarchs' Treaty of Alcázovas-Toledo (1478) that Castile assumed control and possession of the archipelago. From that point on, the islands were a key enclave in the expansionist routes of the Empire, being a key orientation point for navigators aiming to explore and/or trade in the "new world", and staging post for Spanish colonial territories in continental African (Hayek, 2015).

Thus, the contemporary history of the Canary Islands has been linked to relations with the metropolis, at first with the Castilian Empire and, later, with the Spanish state. Initially, this relationship was based on a colonial status that subjected Canarian society to cultural assimilation in different degrees under the political, administrative and educational tutelage of Spain, resulting in the progressive erasure of all precolonial indigenous traits. This resulted in the construction of a singular (and complex) autochthonous population differentiated in many cases from that of the rest of the state given intermingling between the peninsular race and the African Imazighen (Berber) population (Voituriez and Brito, 1982). But the Canary Islands are not only differentiated by their ethnographic elements. The islands' main difference from the rest of Spain resides in its the geographical peculiarity, both in its insular aspect (ie as eight inhabited islands: Lanzarote, Fuerteventura, Gran Canaria, Tenerife, La Gomera, El Hierro, La Palma and La Graciosa) as well as the archipelago's geographical location off the northwest of the African continent, about 1,ooo $\mathrm{km}$ from the Spanish peninsular coast. From this fact, according to Carballo, comes the socalled "geographical dictatorship" over the archipelago:
A perfectly defined territorial space... its territory lacks the characteristics of mainland continuity or contiguity. Both isolating and/or uniting, the ocean creates an identity, a place apart... The territorial unity thus established does not possess ambiguity or allow for alteration of boundaries. (1972: 11 - translation by Marcel Farinelli and Philip Hayward)

Carballo's statement is hardly controversial since situational reality is a fact that can hardly be altered. For example, the island as a geographical expression is difficult to shape, because it is a limited space surrounded by the sea. However, what can be questioned is the relative position islands have in cartographic space. And in this regard the geographic locations that the Canarian archipelago was given in various maps after they were incorporated into the Castilian Empire is illuminating.

\section{A cartographic chronology of the Canarian archipelago}

The Canary Islands supported societies long before their modern conquerors arrived on their shores. In Ancient Greece (90-168 BCE), there were rumours of islands beyond the Columns of Hercules, located in the Garden of Hespérides and referenced in the legend of Atlantis (Martínez, 2009). The Greeks called these islands Makáron nesoi, and later the Romans gave the archipelago the name of Fortunatae. In Map 14 of his Agathademon (in the fourth table of Africa) in his Geographie, Ptolemy places the islands from north to south one below the other in polyhedral form and enumerated them with inaccurate data. This map (Figure 3) is of particular importance since it is the first time that the Canary Islands were represented with proper names (Bonnet and Reverón, 1926). 


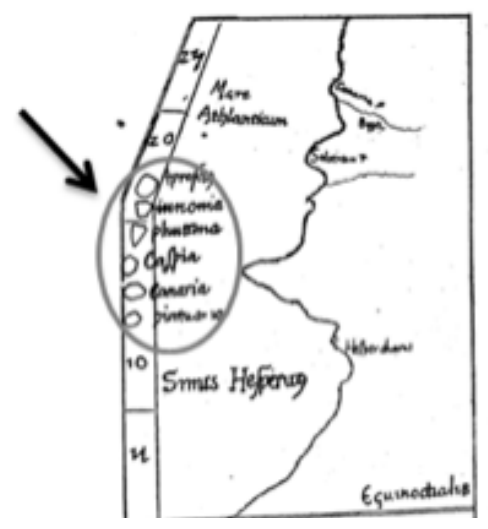

Figure 3 - Sketch of the area of Ptolemy's map that refers to the Canary Islands (extracted from Bonnet and Reverón, 1926).

By the Middle Ages, San Isidoro de Sevilla (56o-636 AD) had produced a map (Figure 4) that showed the islands located parallel to the African continent, with a description that says: For tu natae in su lae ('Fortunate islands').

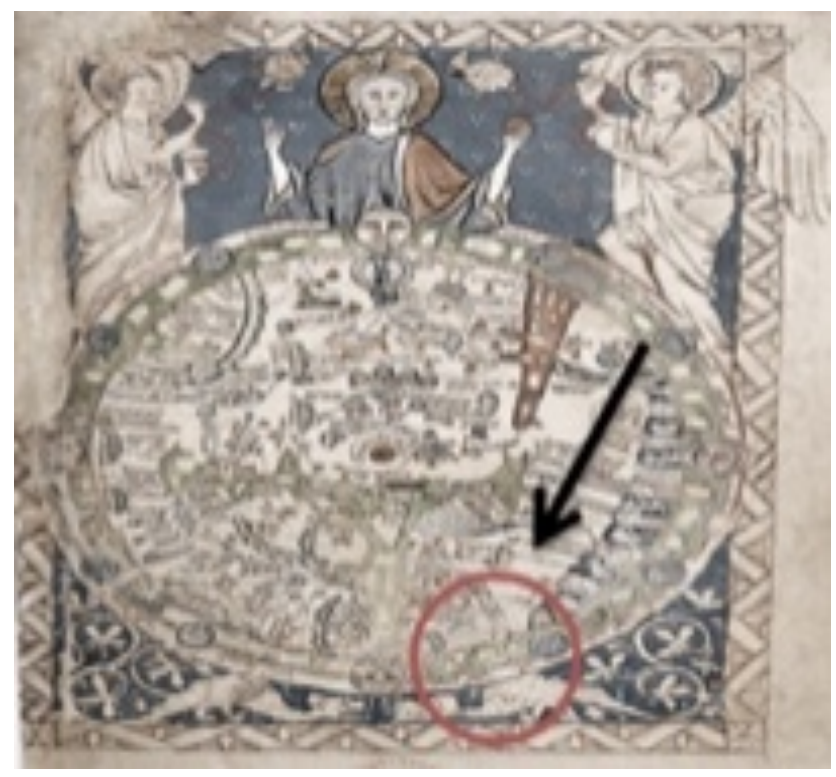

Figure 4 - World map type T in O de San Isidoro (12th Century) (https://metode.es/).

At the time of colonial expansion, and with cartographic elaboration through portulanas ("guide maps"), the islands appear for the first time in a map by the Mallorcan Angelino Dulcert in 1339 that shows where the islands of Lanzarotus Marocellus appear (indicated with the cross of San Jorge to show the Genoese discovered the island), Forte ventura and Vegi Mari (Rodríguez, 2015). Later, in the Catalonian Atlas of 1375 prepared by Cresques Abraham, the entire Canary Islands are represented, except for the island of La Palma (Tous, 
200o). Thus, there are innumerable portulanas where the Canary archipelago is represented, such as the Mediceo Laurentino Atlas of 1351 (Figure 5).

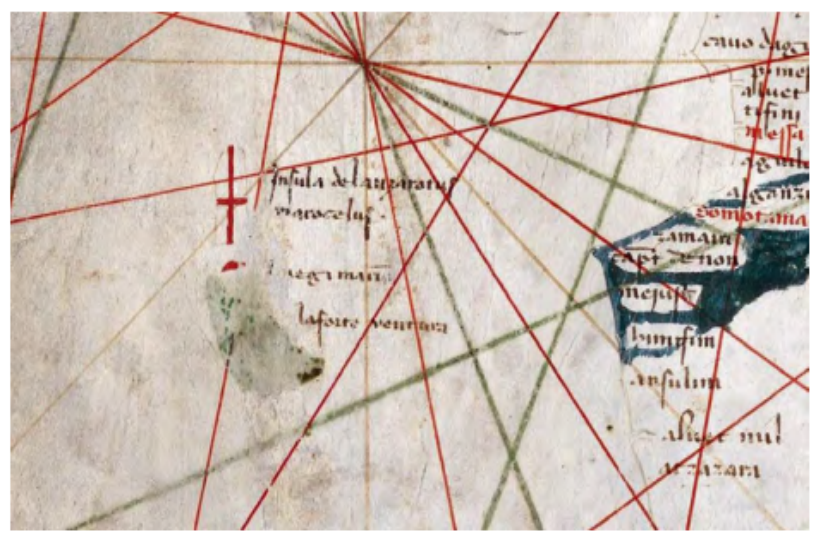

Figure 5 - Portulana by Angelino Dulcert, 1339 (source: Extracted from Rodríguez, 2015).

In the $15^{\text {th }}$ Century the Canary Islands were claimed by the kingdom of Castile (in the central part of modern-day Spain) and a map produced by a Frenchman named Briet in 1648 (Figure 6) placed the Canarian archipelago in a relatively accurate position (if the scale of the cartography is taken into account).

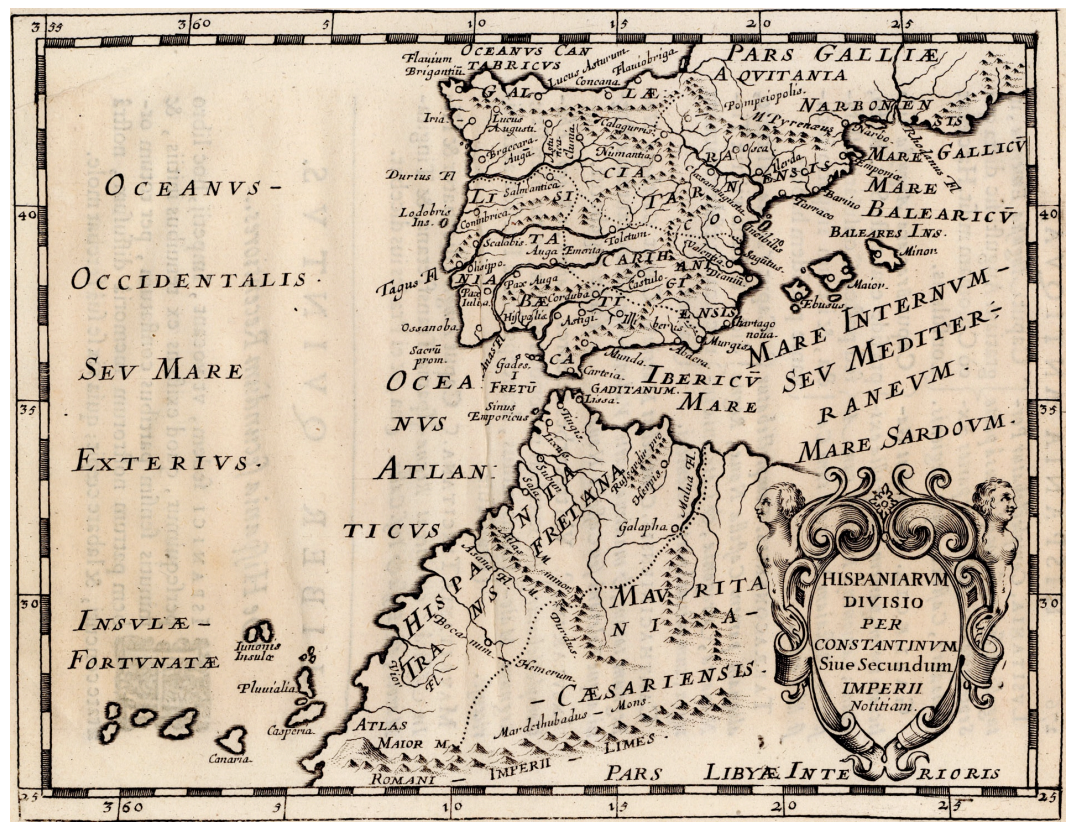

Figure 6 - General map of Spain, 1648 (source: Cartographic Fund of the National Geographic Institute of Spain). 
In 1856, during the reign of Isabel II, a map of Spain was published that includes references to the provinces and the islands. Its author is the geographer Pedro Martín de López and it locates the Canary Islands on the lower left side, inserted into a rectangle. Shortly afterwards, a political-administrative map was published with a representation of the Canary Islands. Its cartographer, Francisco Coello, shows the Iberian Peninsula, the Balearic Islands and the Canary Islands divided into two. On the one hand, in the lower left - and within a rectangle - the islands of El Hierro, La Palma, Tenerife and Gran Canaria; on the other, in the lower right -and also within a rectangle - the islands of Lanzarote, Fuerteventura and, again, Gran Canaria. Thus, this cartography shows an extreme distortion of the archipelago since it divides the islands into two distinct spaces, (even though they were a single province is at that time) and represents the island of Gran Canaria twice.

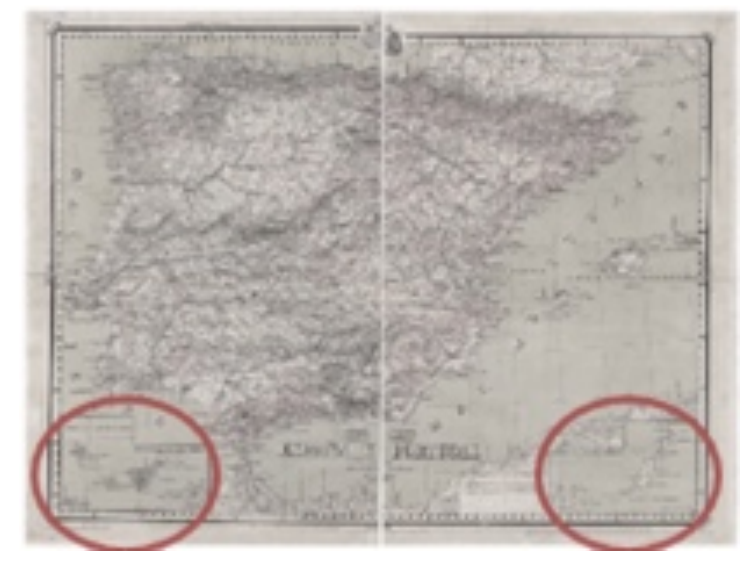

Figure 7 - General map of Spain, 1862 (source: Cartographic Fund of the National Geographic Institute of Spain).

Moving forward historically to 1920 the political-administrative map of Spain made by Benedicto Torres located the Canary Islands in the lower right part of a rectangle.

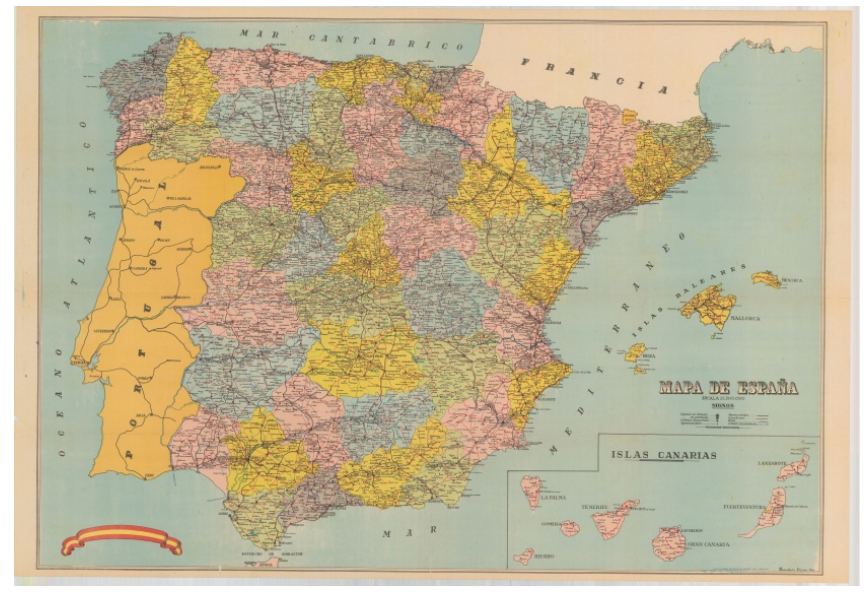

Figure 8 - General map of Spain, 1920 (source: Cartographic Fund of the National Cartographic Institute of Spain). 
After 1920, in successive maps from 1942, 1950, 1963 and 1974 the islands are located at a specific spatial point, at lower right of peninsular Spain and always demarcated by a rectangular outline (eg Figure 9).
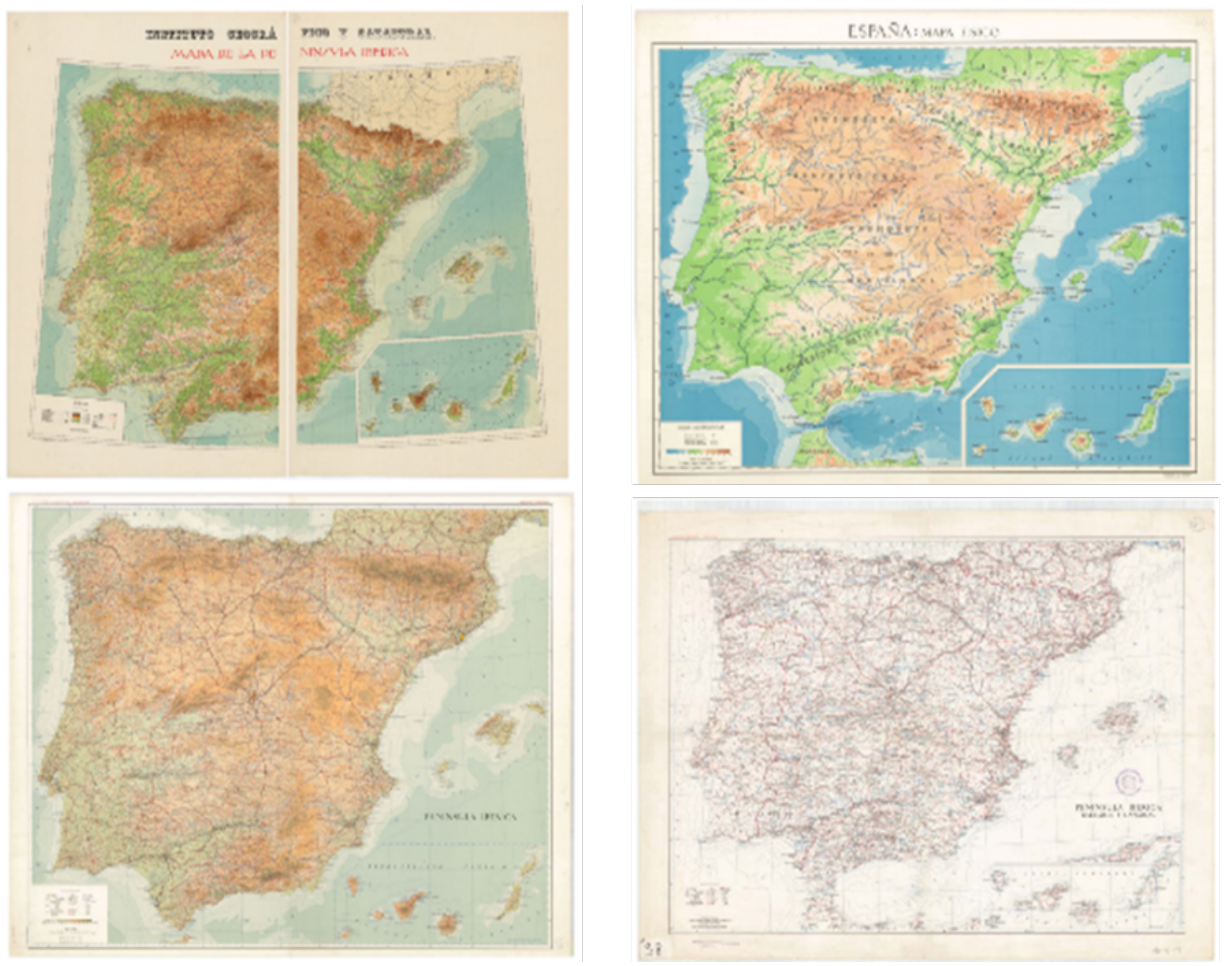

Figure 9 - General maps of Spain, 1942, 1950, 1963 and 1977 respectively (source: Cartographic Fund of the National Geographic Institute of Spain).

After the transition to democracy at the end of the 1970s, a new system of administrative and political decentralisation was extended to 17 autonomous communities, one of them being the Autonomous Community of the Canary Islands. Given developments in public education in the 1980 s that de-emphasised both the doctrine of national unification and the more general indoctrination of the Francoist authoritarian regime, we might have expected that new maps of Spain would reflect the position of the islands more accurately. But in the following map from 1989, the islands are still located in the same place as the previous maps, lower right and within a rectangle. Thus, no modification is observed in the way in which the archipelago is positioned. 


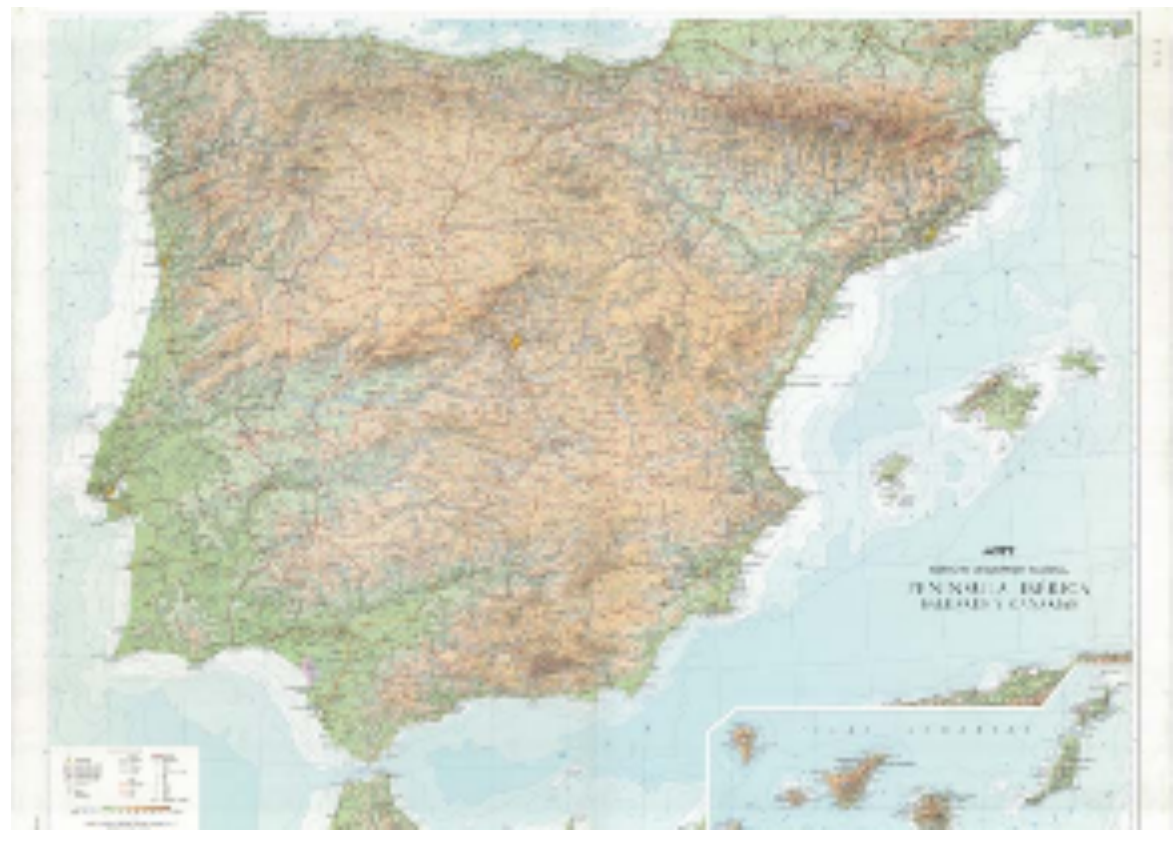

Figure 10 - General map of Spain, 1989 (source: Cartographic Fund of the National Cartographic Institute of Spain).

\section{The (colonial) identity of the Canary Islands}

Over time the cartography of the Canary Islands has been subject to constant variations, malleability and distortion. In this, maps of the archipelago cease to function as guides but are, rather, an effect of the construction of geographical imaginaries that move away from reality. It is not inconsequential that Canarian identity, as well as the perception that can be generated from the archipelago, from the Iberian Peninsula and the rest of the world, are influenced by this cartographic construction.

This cartography has had several effects on Canarian identity. In the first place, Canarian society has been involved in a denial of recognition of its geographical reality. Africa has been eliminated from the "self" and there is no affective relationship between the archipelago and Africa beyond geopolitical and geostrategic rhetoric. Canary Island society has thereby suffered a "conventional split" as a result of historiographical colonialism and the absence of a recognised and referential nationality. As Quintana points out in his prologue to Fernández Cabrera's Mis patrias y otros escritos (1991):

From the 15th Century on, Canarians were considered Africans. Islandness or "Canarianess" was presented as a form of Africanism that - for cultural, political and social reasons - needed to be hidden ... [In order] to improve their position in society, and their individual position, [Canary] Islanders have had to discard whatever is Africanist; but in doing so, Canarians have been left 


\section{Corujo Hernández: Colonial Cartography of The Canary Islands}

without national identity and are, therefore, essentially "orphans", compared to other Africans. (1991: 14 - translation by Marcel Farinelli and Philip Hayward).

For Quintana, Canarian society was marked by a "cultural eclecticism" that recognised its Spanish (European) and American influences but rejected African ones. He goes on to allude that:

The Canaries were alternately Americanist, pro-European, Spanish, or all these things at the same time; daring to assume their own geohistorical nationality forced them to be Africanists, and this then was not available to all intelligences. (ibid: 15)

Other consequences arise from the colonial reality of the archipelago in both its cultural and geographical aspects. As explained by Hernández in his work Natura y Cultura de las Islas Canarias, Canarian society is characterised by:

a) an undervaluation of the ego, considering others as superiors and feeling devalued;

b) a linguistic inferiority with respect to the conventional Castilian language;

c) [a sense of] a fatherless society... [one] that is happy and melancholic at the same time;

d) a cosmopolitan attitude [combined with] a peripherical marginalisation

e) intrapunition - a sense of aggression towards the self that gives rise to frequent self-criticism, irony, jokes and even sadism;

f) slyness, as a defence mechanism against exploitation and as sign of a lack of consciousness as a people. (1986: 427 - translation by Marcel Farinelli and Philip Hayward).

For Alemán (2006), Canarian colonisation was carried out under a single model, namely a European one that turned the islands into a "test bench" for approaches later applied to America. In the same way, Febles and Reyes (2011: 191) argue that in the Canary Islands, environmental and cultural stimuli were forged through elements and figures that exalted the colonising movement (such as the names of the streets, leisure centres, institutions, etc.), provoking a particular Canarian cosmovision. Febles and Reyes emphasise that the Canary Islands suffered a material, historical and dialectical process, a "colonized syndrome" that:

leads to "endophobia", that is, the rejection of the natural; of the native, of the indigenous; of the one belonging to the territory; both by ius solis (the right to nationality those born in the place) and by ius sanguinis (the right to nationality for those descended from someone born in the place). (Benitez, 2011: 17 - translated by Marcel Farinelli).

The Canary Islands' colonial status generated social, cultural, political and economic dependence. Rather than "external" or "classical" colonialism, this involved a type of "internal" colonialism (González, 2003). This created "sociological estrangement" in Canarian society in terms of the relationship of between the dominant political groups of the interior (cacique-bourgeoisie) the foreign (ie Spanish) power) engendered by foreign capital and unequal treatment by the state (Voituriez and Brito, 1982: 18). 
Another element that has affected Canarian identity concerns the anthropological and archaeological distortion of the original peoples. According to Farrujia (2009; 2017), Canarian indigenous identity was deformed from the 14th Century onwards, as its perceptions of origin were distorted by dominant political interests. The colonial archaeology of the 19th and 2oth centuries began to develop disparate and contradictory versions of the past of the Canary Islands and its original people, cataloguing them in different versions as descendants of the Celts or, in an attempt to link European evolutionary development with the Canary archipelago (and/or Africa), of early Cro-Magnon humans. ${ }^{2}$ During the period of the Franco dictatorship (1936-1975), the Ibero-Mauritanian origin of the Canarian natives continued to be prominent in the face of patriotic and religious indoctrination (Farrujia and Aguilar, 2004). The consequence of these processes is the construction of a manipulated and malleable Canarian identity. (Farrujia, 2009).

Despite the above, Canarian identity has undergone a process of transformation in recent decades thanks to the opportunities offered by the political changes that occurred after the proclamation of the Spanish Constitution of 1978. This framework is characterised by a decentralisation of competence and politics towards the Autonomous Communities (CCAA in its acronym in Spanish) in a structure that is similar to the federal model (Stepan, 2001). These structures of self-government, which intermediate between the state and local power, have created differentiated electoral and social and economic spaces that make possible the socialisation of an identity peripheral to that of the nation-state.

However, even before the process described above, regional territorial identification had consolidated as the archipelago experienced a boom of political and cultural selfconsciousness during the final years of the Franco regime. Movements in favour of the selfdetermination of the archipelago identified their colonial status in an attempt to align their enterprise with the African decolonisation processes of the 196os (Hayek, 2013; Rodríguez and García, 2017). Subsequently, demands for autonomist self-determinism were weakened while self-government was reinforced and entered into a context of democratic freedom and economic development. In this framework, nationalist and regionalist organisations emerged in search of administrative power with messages that emphasised the objective differences of the archipelago and the need for it to have its own legal and economic framework without splitting from the nation-state. The Statute of Autonomy of the Canary Islands (EAC, by its acronym in Spanish) approved in 1982 would open a path of selfgovernment and cultural and political recognition unparalleled in the archipelago's colonial history. In parallel, under the mantle of public education and competition, the CCAA took the first steps in the construction of new perceptions and expressions of "Canariety."

According to the psychologist Manuel Alemán:

Canary consciousness permeates instances of emotion and mobilises zones of the feeling. Without the feeling of "canariety" there is no Canarian identity. It presupposes, of course, the existence of the objective elements that distinguish our land, but the identity exists to the degree that such elements are consciously captured and experientially sensed. This experiential feeling is the vertex in which the objective and psychological factors of "canariety" converge and are assembled. (1985: 17 - author's translation)

\footnotetext{
${ }^{2}$ See the discussions summarised in Farrujia (2018).
} 
But in fact, canariety has been used as a political artifact by the elites as a diffuse and rhetorical element remote from that of actual political consciousness. This identity has, thereby, been built around stereotypes that have been permeated in consonance with colonial mystifications and fetishisms. The exotic tropical landscape of good weather and great beaches, the "soft" and "affectionate" Canarian dialect, or the "paused", "flattened" and "happy" lifestyle are elements, among many others, that structure a cultural identity that has been posed as the true essence of the Canarian people. But, on the contrary, as Benitez puts it:

They suffer from that indefinable something that leads us to identify ourselves spiritually with them and with what they represent, even unwittingly, unconsciously... They often stay in the anecdotal or folkloric and, although they may make the sensibility of some social sector vibrate, they are not able to transmit their message to more than a specific group or to the inhabitants of an island, and not to the set of them, as a logical consequence of the territorial division and of the absence of an authentic regional feeling. (2002: online- author's translation).

Therefore, canariety has been an element in the construction of a folkloric and idyllic landand culture-scape that impedes the development of a political identity in the collective unconscious. The trivialisation of this impulse can be observed in all kinds of social practices. In addition, it should be noted that historical and geographical elements have been molded in a banal manner. An example of this is the reconstruction of the image of the contemporary Canarian aborigine. As Estévez identifies:

The "Guanches" (the pre-colonial Canarian aborigines) came to life only when we made them the archetypal image of the Canary, the preeminent embodiment of our self-portrait, in our historical, anthropological, archaeological, social, cultural and political imagination. The "Guanche", in short, was an invention that provided premodern ancestors the modern idea of a Canarian nation as the result of the assimilation of European racist and nationalist ideologies by the elites as a device of social hegemony... The Canarian elites have been identified throughout history to, precisely, bleach, Europeanize and Christianize, in short, to purify their own mestizo and Creole nature... The whole discussion about the origins of the "Guanches" has not been, in the end, more than a chapter of Orientalism in North Africa. (2011: 163 - author's translation)

These aspects do not come from a strictly circumscribed practice in the Canary Islands but, rather, have gone hand in hand with Spanish identity transformation itself with respect to the recognition of its historical link with the African continent. For Martin-Márquez (2011) Spanish identity was molded through the discursive representations that have been made about Africa in consonance with the sense of "Orientalism" proposed by Said (2002). In the Spanish case, the connection with Africa was made around an ambiguous imaginary, provoking what Martin-Márquez (2011) has described as "disorientation", that is the inability of the Spanish cultural elites to locate positive historical markers for the sake of building a sense of nationality without falling into a process of "self-differentiation". This disorientation is reflected in the Canarian archipelago with an important nuance. The positioning of a European "self" is not opposed to the recognition of an African "other", but the same African "self". Canarian citizens, not recognising their African "selves", do not know their origin and spatial location. Africa is seen from the islands in a condescending 
manner, reflecting a perception that the archipelago is an enclave of the first world that has nothing to do with the poor, tortuous (and largely) unknown continent to their immediate east. The African continent becomes distant in that the Canarian collective imagination is located in latitudes closer to Europe. In the same way, "ultra-periphery" (with regard to Europe) " a new status for territories that are in a "spatial limbo" - such as regions that are neither European, nor African, nor Latin American but primarily Atlantic. This "Atlanticism" follows the stereotyped wake of the island peoples in a parallel to the "Antillean" and "Caribbean" conception of other archipelagos.

\section{Conclusion}

Cartography is not an exact or objective science. The power that emanates from the elaboration of graphic representations has substantially determined the manner in which we understand space and the world that surrounds us and where we locate ourselves in it. Throughout history, political geography has influenced the cognitive construction of societies and peoples since it has the capacity to create ideas that facilitate the understanding of reality by simplifying it and offering it descriptively. This was the case in the colonial period and during imperial expansion when elaborated cartographies of great political intentions were drawn up. The map "logo" was, for the communities under consideration, a tool of sociabilisation and national construction that was biased and controlled from metropolises leading, in many cases, to the elaboration of banal identities.

As has been discussed, the cognitive construction of the Canarian archipelago through colonial cartography has identified how the Canary Islands have been given a malleable and distorted character. There are few cartographies that locate the archipelago correctly in an objective sense, undermining the geographical reality that the archipelago has and frustrating the Canarian population's ability to construct a more objective reality. Canary Islands society has undergone a process of singular identity elaboration in a tricontinental territory far from its "parental" nation-state as a de facto Spanish colony. This has had consequences both in perceptions of the geographical position of the islands, located according to convenience and justified under rationalising space imperatives, as it has in the ethnographic and archaeological distortion of the pre-colonial culture by a dominant power that has involved the elaboration of a malleable identity and lack of self-consciousness as a political community.

\section{BIBLIOGRAPHY:}

Alemán, M (2006) Psicología del Hombre Canario, Santa Cruz de Tenerife: Instituto Psicosocial Manuel Alemán

Allen, C (1998) 'Creole Then and Now: The Problem of Definition', Caribbean Quarterly v44 n1-2: $33-49$

Anderson, B (1991) Imagined Communities: Reflections on the Origin and Spread of Nationalism (Revised edition), London: Verso 
Baldacchino, G (2007) 'Editorial: Introducing a World of Islands', in Baldacchino, G (ed) A World of Islands: An Islands Studies Reader, Charlottetown: Institute of Island Studies, University of Prince Edward Island: 1-29

----- (2008) 'Studying Islands: On Whose Terms? Some Epistemological and Methodological Challenges to the Pursuit of Island Studies', Island Studies Journal v3 n1: 37-56

Baldacchino, G and Royle, S (2010) 'Postcolonialism and Islands: Introduction', Space and Culture n2: 140-143

Benítez, J (2011) ‘Endofobia en Canarias', Revista electrónica de Psicología Política n25: 16-20

Benítez, L (2002) 'La identidad canaria': amigos25dejulio.com: http://amigos25julio.com/index.php?option=com_content\&view=article\&id=415:la-

identidad-canaria\&catid=20\&Itemid=99 - accessed 18th May 2018

Billing, M (2014) Nacionalismo Banal, Madrid: Capitán Swing

Bonnet y Reverón, B (1926) 'La geografía de Ptolomeo y las Islas Canarias', Revista de Historia v2 n9: $3-6$

Carballo, A (1972) Canarias, región polémica. Análisis crítico de régimen económico-fiscal del Archipiélago, Las Palmas de Grand Canaria: ITS: Cuadernos para el Dialogo

Crampton, J and Krygier, J (2010) 'An Introduction to Critical Cartography', ACME: An International E-Journal for Critical Geographies n4: https://www.acmejournal.org/index.php/acme/article/view/723

Cruz, C and Darias, O (2011) 'Descripción psicológica de la sociedad Canaria, Consecuencias de la colonización, Revista electrónica de psicología política n26: 130-208

Cubera, C (2011) 'Caribbean Insular Mobilities', Suomen Antropologi: Journal of the Finnish Anthropological Society v36 n1: 5-25

During, S (1992) 'Postcolonialism and globalization: A dialectical relation after all?', Meanjin v51 n2: 339-353

Estévez, F (2011) 'Guanches, magos, turistas e inmigrantes: canarios en la jaula identitaria', Revista Atlántida n3: 145-172

Fanon, F (2011) Los condenados de la tierra, México City: FCE

Farrujia de la Rosa, A and Aguilar, M (2004) 'La arqueología canaria bajo el régimen franquista: el tema del primitivo poblamiento de las islas como paradigma (1939-1969)', Trabajos de Prehistoria v61 n1: 7-22

Farrujia de la Rosa, A (2009) 'El poblamiento "amazigh" de las islas Canarias: problemas identitarios', Makaronesia: Boletín de la Asociación de amigos del Museo de Ciencias Naturales de Tenerife nı1: 54-69 


\section{Corujo Hernández: Colonial Cartography of The Canary Islands}

----- (2017) "Culture Beyond Borders: the Amazigh Past of the Canary Islands', Journal of Historical Archaeology and Anthropological Sciences vi n6: 2-4

Febles, C.J and Reyes O (2011) 'Descripción Psicológica de sociedad canaria. Consecuencias de la colonización’, Revista electrónica de Psicología Política n26: 130-208

Firth, R (1936) We, The Tikopia: A Sociological Study of Kinship in Primitive Polynesia, Stanford: Stanford University Press

García, C (2006) 'Islas de ida y Vuelta: Canarias y el Caribe en contexto colonial', Revista de dialectología y tradiciones populares v61 n2: 191-208

González, P (2003) ‘Colonialismo interno (una redefinición)’, Rebeldía nı2: 1-30

Harley, J (2005) La nueva naturaleza de los mapas: Ensayos sobre la historia de la cartografía, México: FCE

Hayek, D (2013) 'Canarias en la geopolítica del franquismo durante las independencias africanas en 1960', Geopolitica(s) v4 n2: 263-28o

----- (2015) Geopolítica, nacionalismo y tricontinentalidad, La Laguna: Latina

Heffernan, M (2002) 'The politics of the map in the early twentieth century', Cartography and Geographic Information Science v29 n3: 207-226

Hernández, P (1986) Natura y Cultura de las Islas Canarias, Santa Cruz de Tenerife: Tafor Ediciones

Hiernaux, D and Lindón, A (2012) 'Renovadas intersecciones: la espacialidad y los imaginarios', in Hiernaux, D and Lindón, A (eds) Geografías de lo Imaginario, España: Anthropos Editorial: 9-28

Jacobs, J (1996) Edge of Empire: Postcolonialism and the city, London: Routledge

Lomano, M (2013) 'Emergence and the Insula Improvisa: St. Brendan's Island and Afro/Canarian (Jazz) Fusion Music', Shima: The International Journal of Research into Island Cultures v7 n2: 92-108

Martínez, M (2011) 'Islas míticas en relación con Canarias', Estudios griegos e indoeuropeos n20: $139-158$

Martin-Márquez, S (2011) Desorientaciones: El colonialismo español en África y la performance de identidad, Barcelona: Ediciones Bellaterra

McCall, G (1994) 'Nissology: A Debate - The Study of Islands', Journal of the Pacific Society v17 n2-3: 1-14

McCusker, M and Soares, A (eds) (2011) Islanded Identities: Constructions of Postcolonial Cultural Insularity, New York: Rodopi 


\section{Corujo Hernández: Colonial Cartography of The Canary Islands}

Montoya, V (2007) 'El mapa de lo invisible: Silencios y gramática del poder de la cartografía', Universitas Humanística n63: 155-179

Moore, A and Perdue, N (2014) 'Imagining a Critical Geopolitical Cartography', Geography Compass v8 n12: 892-901

Núñez, A, Zambra, A and Aliste, E (2017) 'El poder de los mapas, los mapas de poder: la construcción del saber geográfico en la Patagonia-Aysén', UNIVERSUM v3 n2: 149-162

Piccolotto, B (2004) 'Decifrando mapas: sobre o conceito de "território" e suas vinculaçoes com a cartografia', Annais du Museu Paulista v12 n12: 193-234

Quintana, P (1991) 'Prólogo', in Cabrera, F (ed) Mis patrias y otros escritos, Santa Cruz de Tenerife: Centro de la Cultura Popular: 9-19

Rodríguez, F and García, J (2017) 'La guerra de las pulgas: Propaganda armada, caudillismo y delación en el MPAIAC', Anuario de estudios Atlánticos n63: 1-20

Rodríguez, K (2015) 'Descubriendo el velo. El recuerdo medieval de las Afortunadas en los portulanos Mediterráneos del XIV', Revista de Historia Canaria nı97: 237-261

Royle, S (2010) 'Postcolonial Culture on Dependent Islands', Space and Culture v13 n2: 203215

Said, E (2002) Orientalismo, Barcelona: Debate

Salgado, J and Reyna, J (2017) ‘Todas las cicraticez: Hacia una fenomenología de lo colonial en Frantz Fanon', Intersticios v6 n12: 31-65

Tajfel, H (1984) Grupos humanos y categorías sociales, Barcelona: Herder

Taylor, P and Colin, F (2002) Geografía política: economía mundo, estado-nación y localidad, Trama Editorial

Tous, J (2000) 'Canarias en la cartografía histórica', in Morales, M, and Pérez, G (eds) Gran Atlas temático de Canarias, City: Editorial Interinsular Canaria: 11-21

Voituriez, A and Brito, O (1982) Canaria: Encrucijada internacional, Santa Cruz de Tenerife: Ecotopia 